\title{
PROTECTIVE EFFECT OF PHILESIA MAGELLANICA (COICOPIHUE) FROM CHILEAN PATAGONIA AGAINST OXIDATIVE DAMAGE
}

\author{
MARIO SUWALSKY $Y^{*}, 1$ MARCIA AVELLO², JOSÉ OBREQUE ${ }^{2}, F E R N A N D O$ VILLENA ${ }^{3}$, RENATA SZYMANSKA4, \\ ANNA STOJAKOWSKA ${ }^{5}$, KAZIMIERZ STRZALKA ${ }^{4}$
}

\author{
${ }^{1}$ Faculty of Chemical Sciences, University of Concepción, Concepción, Chile \\ ${ }^{2}$ Faculty of Pharmacy, University of Concepción, Concepción, Chile \\ ${ }^{3}$ Faculty of Biological Sciences, University of Concepción, Concepción, Chile \\ ${ }^{4}$ Faculty of Biochemistry, Biophysics and Biotechnology, Jagiellonian University, Kraków, Poland \\ ${ }^{5}$ Institute of Pharmacology, Polish Academy of Sciences, Krakow, Poland
}

\begin{abstract}
Philesia magellanica (P. magellanica) is a plant collected in the Chilean Patagonia. Its antioxidant properties were assessed in human erythrocytes exposed in vitro to oxidative stress induced by $\mathrm{HClO}$. Scanning electron microscopy (SEM) observations showed that $\mathrm{HClO}$ induced a morphological alteration in the red blood cells from a normal discoid to a spherocytic form, and cells of unequal size. However, a concentration as low as $1 \mu \mathrm{M}$ gallic acid equivalents (GAE) of $P$. magellanica aqueous extract neutralized the change effects of $50 \mu \mathrm{M} \mathrm{HClO}$. On the other hand, $20 \mu \mathrm{M}$ (GAE) of the extract considerably reduced the deleterious capacity of $0.25 \mathrm{mM} \mathrm{HClO}$ to induce hemolysis in red blood cells. In addition, X-ray diffraction experiments were performed in molecular models of the human erythrocyte membrane. These consisted in multilayers of dimyristoylphosphatidylcholine (DMPC) and dimyristoylphosphatidylethanolamine (DMPE), classes of lipids preferentially located in the outer and inner monolayers, respectively of the human erythrocyte membrane. It was observed that $P$. magellanica only interacted with DMPC affecting its multilayer structure. It was also observed that $0.1 \mu \mathrm{M}(\mathrm{GAE})$ of $P$. magellanica neutralized the structural perturbation induced by 0.05 and $0.5 \mathrm{mM} \mathrm{HClO}$. These experiments confirmed the antioxidant properties of $P$. magellanica aqueous extracts.
\end{abstract}

Keywords: Philesia magellanica; Coicopihue; Plant extract; Antioxidant; Human erythrocyte; Cell membrane.

Abbreviations: P. Magellanica, Philesia Magellanica; GAE, gallic acid equivalents; SEM, scanning electron microscopy; RBCS, red blood cell suspension; DMPC, dimyristoylphosphatidylcholine; DMPE, dimyristoylphosphatisylethanolamine, ROS, reactive oxygen species.

\section{INTRODUCTION}

Patagonia is the southernmost region of Argentina and Chile. The Eastern side of the mountains is covered by broad steppe with low shrubs and small perennials. ${ }^{1}$ We report here our study on the native bush Philesia magellanica J.F. Gmel. Philesiaceae (Coicopihue) (P. magellanica) (Fig. 1).

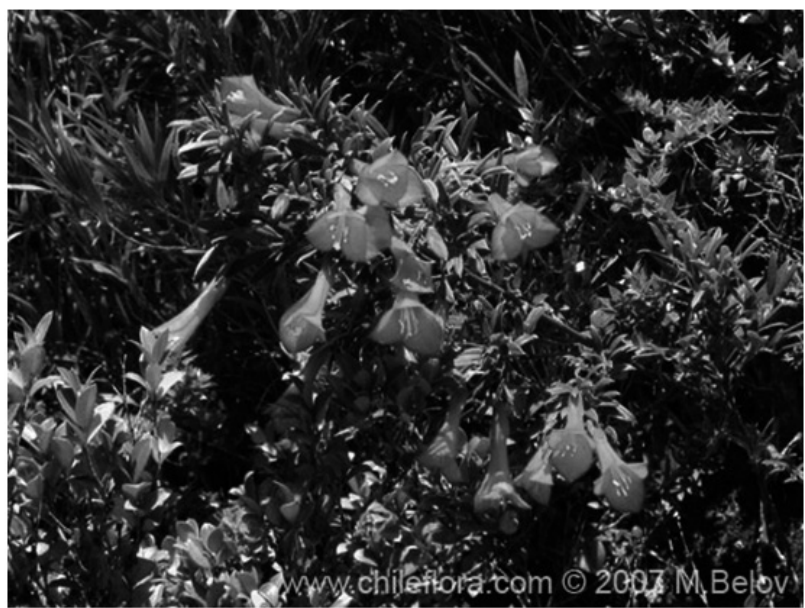

Fig 1. Philesia magellanica J.F. Gmel. Philesiaceae (Coicopihue) ( $P$. magellanica) (www.chileflora.com)

The lack of knowledge about the potential use of $P$. magellanica in alternative medicine as an antioxidant and its toxicity as well as the particular interest of a plant growing in extreme environmental conditions lead us to investigate the plant's effects on cell membranes. Analyses of the plant extracts showed that contained flavonoids, of which their antioxidant properties have been extensively explored..$^{2-3}$ It has been estimated that about $2 \%$ of the oxygen used by cells forms reactive oxygen species (ROS). ${ }^{4}$ When the ROS production overcomes the antioxidant defense barriers, damage of cellular structures and functions is produced. This process, known as oxidative stress, leads to pathologies such as atherosclerosis and cancer, and ultimately to cell death. ${ }^{5}$ The main ROS are the superoxide anion $\left(\mathrm{O}_{2}^{\circ}\right)$, the hydroxyl $\left(\mathrm{OH}^{\circ}\right)$ free radicals and singlet oxygen $\left({ }^{1} \mathrm{O}_{2}\right)$ which may damage cell molecules such as lipids, proteins, carbohydrates, DNA and lipoproteins. ${ }^{6}$ The antioxidants are molecules that scavenge ROS and also can stop their formation in the cells, thus limiting their harmful effects. The molecular mechanisms of the antioxidant action of flavonoids have not been fully elucidated. However, it has been suggested that the ability of these compounds to partition in cell membranes and the resulting restriction on their fluidity could sterically hinder diffusion of ROS and thereby decrease the kinetics of their reactions. ${ }^{7-8}$ On the other hand, the toxic side effects of plant extracts are increasingly considered. ${ }^{9-10}$

This article describes the interaction of aqueous extracts of $P$. magellanica with human erythrocytes and molecular models of the erythrocyte membrane. The cell membrane is a diffusion barrier which protects the cell interior. Therefore, its structure and functions are susceptible to alterations as a consequence of interactions with exogenous species. Erythrocytes were chosen because although their membranes are less specialized than many other cell membranes they carry on enough functions in common with them such as active and passive transport and the production of ionic and electric gradients to be considered representative of the plasma membrane in general. Oxidants produce alterations in the erythrocyte membrane as manifested by a decreased cytoskeletal protein content and production of high molecular weight proteins which can lead to abnormalities in erythrocyte shape, rheological properties and release of hemoglobin. ${ }^{11-12}$ To better understand the molecular interactions of $P$. magellanica with the erythrocyte membrane we utilized molecular models consisting in multibilayers of dimyristoylphosphatidylcholine (DMPC) and dimyristoylphosphatidylethanolamine (DMPE), representative of phospholipids classes located in the outer and inner monolayers of the human erythrocyte, respectively. ${ }^{13-14}$ The capacity of $P$. magellanica to perturb the bilayer structure of DMPC and DMPE was evaluated by X-ray diffraction.

These systems and techniques have also been used in our laboratories to determine the effects of Ugni molinae (Murtilla) leaves and fruit, ${ }^{15-17}$ Aristotelia chilensis (Maqui) leaves, ${ }^{18}$ and Balbisia peduncularis (Amancay) stems ${ }^{19}$ infuses on human erythrocytes.

Hypochlorous acid $(\mathrm{HClO})$ is a powerful natural oxidant that damages bacteria, endothelial cells, tumor cells and erythrocytes. ${ }^{20-21}$ In this work, the antioxidant properties of $P$. magellanica were evaluated in human erythrocytes 
exposed in vitro to the oxidative stress induced by $\mathrm{HClO}$. The experiments were carried out by means of scanning electron microscopy (SEM), hemolysis measurements and X-ray diffraction.

\section{MATERIALS AND METHODS}

\subsection{Chemicals}

Sodium hypochlorite ( $\mathrm{NaClO}$ ) (Sigma, $\mathrm{MO}, \mathrm{USA})$; at $\mathrm{pH} 7.4 \mathrm{NaClO}$ exists as $\mathrm{HClO}$ and $\mathrm{ClO}^{-}$in an approximately equimolar ratio, ${ }^{11,24}$ and is referred to hereafter as $\mathrm{HClO}$; its concentration was spectrophotometrically determined at $292 \mathrm{~nm}\left(\mathrm{e}=350 \mathrm{M}^{-1} \mathrm{~cm}^{-1}\right),{ }^{25}$ Folin-Ciocalteu reagent (Merck, Germany); dimyristoylphosphatidylcholine (DMPC, lot 140PC-224, MW 677.9) and dimyristoylphosphatidylethanolamine (DMPE, lot 140PE-54, MW 635.9) (Avanti Polar Lipids,ALA, USA); composition of phosphate buffered saline (PBS) was $150 \mathrm{mM} \mathrm{NaCl}, 1.9 \mathrm{mM} \mathrm{NaH}{ }_{2} \mathrm{PO}, 8.1 \mathrm{mM} \mathrm{Na}_{2} \mathrm{HPO}_{4}$, pH 7.4; saline solution $(0.9 \% \mathrm{NaCl}, \mathrm{pH} 7.4)$.

\subsection{Plant material}

Leaves of P.magellanica were collected from natural stands in the Chilean part of Patagonia (Puyuhuapi, 44 $21^{\prime} \mathrm{S}, 7^{\circ} 34^{\prime} \mathrm{W}$ ) during 2008 Southern Hemisphere summer. Specimens were identified by Dr. Roberto Rodríguez at the Department of Botany, University of Concepción, Chile, and a voucher specimen was deposited at its herbarium (CONC 177959).

\subsection{Qualitative and quantitative analysis of extract species}

\subsubsection{Estimation of total phenolic content}

A reducing capacity of the plant material (total phenolic content) was spectrophotometrically determined (Bausch \& Lomb SP2000UV, USA) at 765 $\mathrm{nm}$ by the Folin-Ciocalteu method using Folin-Ciocalteu reagent. ${ }^{26}$ Briefly, aliquots of test samples $(0.5 \mathrm{~mL}$ of $1 \%$ extract) were mixed with $25 \mathrm{~mL}$ of distilled water, $2.5 \mathrm{~mL}$ Folin-Ciocalteu reagent, $10 \mathrm{~mL} 20 \% \mathrm{Na}_{2} \mathrm{CO}_{3}$, and completed to $50 \mathrm{~mL}$ with water, shaken for $30 \mathrm{~min}$ and allowed to react for 30 min. Gallic acid was used as the standard for a calibration curve, and the total polyphenol contents were expressed as gallic acid equivalents (GAE). ${ }^{27}$ Solutions containing a range of polyphenol concentration for the different assays (0.1-10 mM GAE) were attained by dissolving calculated amounts of plant powder in the adequate volumes of distilled water.

\subsubsection{Chromatographic analysis of phenolic acid}

A portion of dry, pulverized plant material $(0.5 \mathrm{~g})$ was suspended in 50 $\mathrm{mL}$ of water and heated under reflux until boiling. After filtration, the water extract was concentrated in vacuo to obtain $10 \mathrm{~mL}$ of condensed solution. The solution was further filtered through the membrane filter (pore size 0.2 $\mathrm{mm}$ ) and an aliquot $(5 \mathrm{~mL})$ of the filtrate was injected into an HPLC system to analyze simple phenolics in unhydrolysed extract. The remaining filtrate was evaporated to dryness under reduced pressure. The residue was dissolved in 10 $\mathrm{mL}$ of $2 \mathrm{M} \mathrm{HCl}$ and heated under reflux for $30 \mathrm{~min}$ to make the hydrolysis as complete as possible. ${ }^{28}$ After cooling, the hydrolysate was extracted three times with $5 \mathrm{~mL}$ of EtOAc. The organic extracts were combined and evapored under reduced pressure. The dry residue was redissolved in $70 \% \mathrm{MeOH}(1 \mathrm{~mL})$ and centrifuged $(11,340 \mathrm{~g}, 5 \mathrm{~min})$ prior to HPLC analysis. Analytical RP-HPLC separations of the samples were performed using an Agilent 1200 Series HPLC system (Agilent Technologies, USA), equipped with a Rheodyne manual sample injector, quaternary pump, degasser, column oven and a diode array detector. Chromatographic separations of phenolics were carried out at $25^{\circ} \mathrm{C}$ on a Zorbax Eclipse XDB-C18 column, 4.6 x $150 \mathrm{~mm}$ (Agilent Technologies, USA), as it was described earlier. ${ }^{29}$ The compounds were semi-quantified using two point calibration curves, based on peak areas measured at $325 \mathrm{~nm}$ (caffeic acid, ferulic acid), $305 \mathrm{~nm}$ (p-coumaric acid) and $250 \mathrm{~nm}$ (p-hydroxybenzoic acid) (concentration range $0.02-0.40 \mathrm{mg} \mathrm{mL}^{-1}$ ). The phenolic acids were identified by comparison of their retention times and UV spectra with those of authentic samples and co-chromatography with standards.

\subsubsection{Isolation of catechin}

Dried and pulverized plant leaves $(0.5 \mathrm{~g})$ were extracted with hot $50 \%$ $\mathrm{MeOH}$, for $30 \mathrm{~min}$, under reflux. The extract, after evaporation under reduced pressure, yielded $117 \mathrm{mg}$ of a dry residue. The residue was suspended in $\mathrm{MeOH}$ $(1.5 \mathrm{~mL})$ and separated by paper chromatoghraphy (filter paper - Whatman $3 \mathrm{MM})$. Solvent system $(15 \% \mathrm{AcOH})$ was applied in descending mode. After chromatographic development, bands showing fluorescence in UV light were excised and separately eluted with $\mathrm{MeOH}$. The band which showed a blue fluorescence and $\mathrm{Rf}$ value of 0.53 , after elution with $\mathrm{MeOH}$ and evaporation of the solvent, yielded yellowish residue $(4.8 \mathrm{mg})$.

\subsection{X-ray diffraction studies of phospholipid multilayers}

Synthetic DMPC and DMPE were used without further purification. About $2 \mathrm{mg}$ of each phospholipid were introduced into $1.2 \mathrm{~mm}$ diameter special glass capillaries (Glas-Technik \& Konstruktion, Berlin, Germany), which were filled with $150 \mathrm{~mL}$ of (a) distilled water and (b) aqueous extracts of $P$. magellanica in a range of concentrations ( $10 \mu \mathrm{M}-10 \mathrm{mM} \mathrm{GAE})$. The specimens were incubated for $1 \mathrm{~h}$ at $30^{\circ} \mathrm{C}$ and $60{ }^{\circ} \mathrm{C}$ with DMPC and DMPE, respectively, centrifuged for $10 \mathrm{~min}$ at $3500 \mathrm{rpm}$ and $\mathrm{X}$-ray diffracted with Ni-filtered $\mathrm{CuK} \alpha$ from a Bruker Kristalloflex 760 generator (Karlsruhe, Germany). Specimen-to-film distances were 8 and $14 \mathrm{~cm}$, standardized by sprinkling calcite powder on the capillary surface. The relative reflection intensities were obtained in a MBraun PSD-50M linear position-sensitive detector system (Garching, Germany); no correction factors were applied. The experiments were performed at $19 \pm$ $1{ }^{\circ} \mathrm{C}$, which is below the main phase transition temperature of both DMPC and DMPE; each experiment was repeated three times. The same procedure was used to study the protective capacity of $P$. magellanica aqueous extracts $(0.1$, 1.0 and $10 \mu \mathrm{M} \mathrm{GAE})$ against the oxidant property of $\mathrm{HClO}(0.05 \mathrm{mM}$ and 0.5 $\mathrm{mM})$. In this case, the assays were performed only in DMPC.

2.5. Scanning electron microscopy (SEM) studies of human erythrocytes

A range of $P$. magellanica aqueous extract concentrations were made to interact in vitro with red blood cells with and without $\mathrm{HClO}$. With this aim, two blood drops from a human healthy donor not receiving any pharmacological treatment were obtained by puncture of the ear lobule and received in an Eppendorff tube containing $100 \mu \mathrm{L}$ of heparin $(5000 \mathrm{UI} / \mathrm{ml})$ in $900 \mu \mathrm{L}$ of saline solution; after centrifuged, (1000 rpm x $10 \mathrm{~min})$ the tube supernatant was discarded and replaced by the same volume of saline solution; the whole process was repeated three times. Fractions of this stock of red blood cells suspension (RBCS) in saline were placed in seven Eppendorff tubes and added to each one different concentrations of the plant aqueous extract and $\mathrm{HClO}$; these concentrations were attained diluting the extract in saline to a final volume of $500 \mu \mathrm{L}$. The aqueous extract solutions used for the preparation of these samples was previously sonicated for $15 \mathrm{~min}$, placed on a thermo regulated bath at $37{ }^{\circ} \mathrm{C}$ and filtered. All the samples were then incubated at $37^{\circ} \mathrm{C}$ for $1 \mathrm{~h}$, period in line with the larger effects induced by compounds on red cell shape ${ }^{30-31}$ They were fixed overnight at $4{ }^{\circ} \mathrm{C}$ with $400 \mu \mathrm{L} 2.5 \%$ glutaraldehyde in distilled water, reaching a final fixation concentration of about $2.4 \%$. Samples were centrifuged (1000 rpm x $10 \mathrm{~min}$.), glutaraldehyde was discarded and replaced (three times) with $400 \mu \mathrm{L}$ of distilled water; about $20 \mu \mathrm{L}$ of each sample was placed on Al glass cover stubs, air-dried at room temperature, gold coated and examined in scanning electron microscopes (Etec Autoscan, Etec Corp., Hayward, CA, USA, and JEOL JSM-6380LV, Japan).

\subsection{Hemolysis assays}

Red blood cells (RBC) were obtained from healthy consenting donors. Heparinized blood was centrifuged (Kubota, Japan) at $2500 \mathrm{rpm}$ for $10 \mathrm{~min}$. After removal of plasma and buffy coat, the RBC were washed three times with phosphate buffer at room temperature, and resuspended in PBS four times its volume for subsequent analyses. ${ }^{32} \mathrm{RBC}(10 \% \mathrm{v} / \mathrm{v})$ were incubated in a shaking bath for $15 \mathrm{~min}$. at $37^{\circ} \mathrm{C}$ in PBS in the presence of $P$. magellanica aqueous extracts $(0.02,0.1,0.3$ and $0.5 \mathrm{mM} \mathrm{GAE}) .0 .25 \mathrm{mM} \mathrm{NaClO}$ was added to the extract as single bolus of a diluted solution in PBS. After 15 min incubation, an aliquot of RBC suspension was centrifuged (EYDAM, Germany) at $2500 \mathrm{rpm}$ for $10 \mathrm{~min}$. Hemolysis was spectrophotometrically evaluated (Jasco, Japan) at $540 \mathrm{~nm}$ as haemoglobin $(\mathrm{Hb})$ released from cells in the supernatant. ${ }^{33}$

2.7. Statistical analysis

Statistical analysis were performed using ANOVA one way and Dunnet test. All data were expressed as mean \pm S.D. of at least three different determinations

\section{RESULTS}

\subsection{Phenolic constituents of $P$. magellanica}

\subsubsection{Total phenolic contents}

Total reducing capacity of the plant material (total phenolic content) was $48.7 \mathrm{mg} / \mathrm{g}$ dry weight (expressed as GAE equivalents), determined by the Folin-Ciocalteau method. This content of phenolics is close to that found in chicory leaves ${ }^{34}$, which are excellent dietary source of antioxidants.

\subsubsection{Phenolic acid analysis}

Chromatographic separations of aqueous extract from $P$. magellanica leaves revealed that free phenolic acids are absent from the analysed solution. However, the UV spectra of major peaks present in the chromatogram (Fig. 2) were identical with those of caffeic and ferulic acid. After acidic hydrolysis of the water extract, the following phenolic acids were found: ferulic acid (Rt $\left.-15.5 \mathrm{~min}, 1_{\max }-318 \mathrm{~nm}\right)-33 \pm 0.80 \mathrm{mg} / 100 \mathrm{~g}$ of dry tissue, caffeic acid (Rt $8.6 \mathrm{~min}, 1-316 \mathrm{~nm})-12 \pm 0.38 \mathrm{mg} / 100 \mathrm{~g}, p$-coumaric acid $(\mathrm{Rt}-12.9 \mathrm{~min}$, $1-305 \mathrm{~nm})-5 \pm 0.40 \mathrm{mg} / 100 \mathrm{~g}$ and $p$-hydroxybenzoic acid (Rt $-12.9 \mathrm{~min}$, $\left.1_{\max }^{\max }-250 \mathrm{~nm}\right)-10 \mathrm{mg} \pm 0.04 \mathrm{mg} / 100 \mathrm{~g}$ (Fig. 2). Limits of detection (LOD) and 
quantification (LOQ) for hydroxycinnamates, under the given chromatographic conditions, were $0.3 \mathrm{mg} / \mathrm{mL}$ and $0.8 / \mathrm{mg} \mathrm{mL}$, respectively.

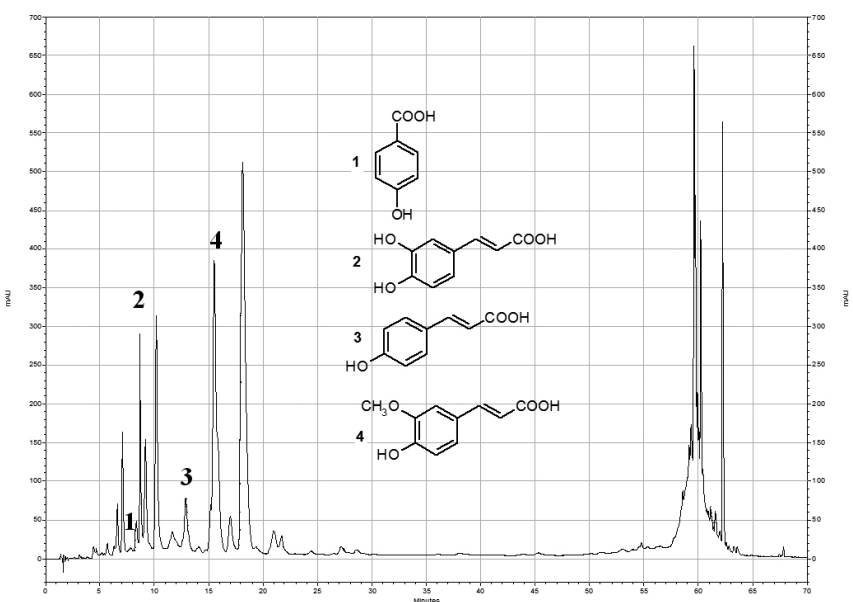

A) After hydrolysis

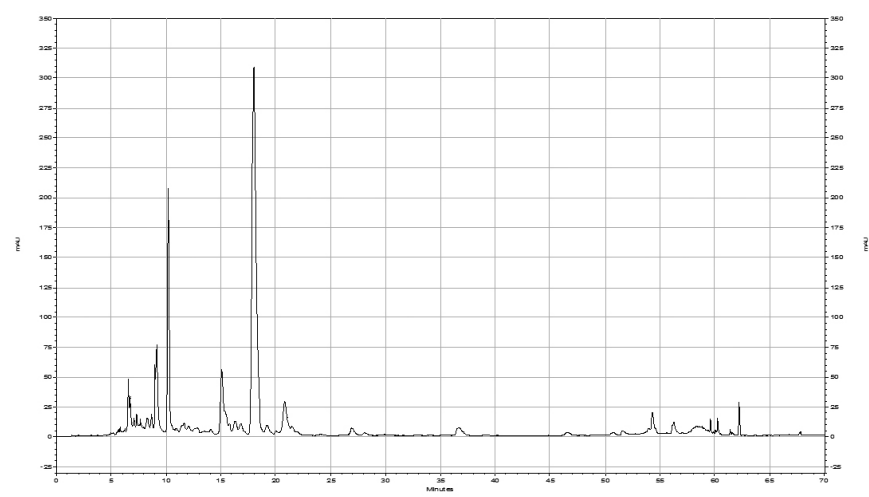

B) Before hydrolysis

Fig. 2: Chromatograms of phenolic acids after (A) and before (B) hydrolysis. 1 - ( $p$-hydroxybenzoic acid, Rt - 7,48 min (the peak is low because absorption maximum of this compound is at $250 \mathrm{~nm}$ and the chromatograms were monitored at $320 \mathrm{~nm}$ ); 2 - caffeic acid, Rt - 8,68 min; 3 - p-coumaric acid, Rt - 12,90 min; 4 - ferulic acid, Rt - 15,53 min).

\subsubsection{Isolation of catechin}

Fractionation of hydroalcoholic extract from the plant leaves yielded catechin - 3',4',5,7-tetrahydroxyflavan-3-ol (4.8 mg, isolation yield - $0.96 \%$ ), which is a well known plant antioxidant and a building block of condensed tannins. The compound was identified by comparison of its spectral data (UV, ${ }^{1} \mathrm{H}$ NMR) to those found in the literature. ${ }^{35}$ Although catechin is less soluble in water than in water-alcohol mixtures, the compound very likely contribute to the antioxidant potential of $P$. magellanica aqueous extract.

\subsection{X-ray diffraction studies of phospholipid multilayers}

Fig. 3A exhibits the results obtained by incubating DMPC with water and aqueous extracts of $P$. magellanica. As expected, water altered the DMPC structure: its bilayer repeat (bilayer width plus the width of the water layer between bilayers) increased from about $55 \AA$ in its dry crystalline form to 64.5 $\AA$ when immersed in water and its low-angle reflections (indicated as LA) were reduced to only the first two orders of the bilayer repeat. ${ }^{36}$

On the other hand, only one strong reflection of $4.2 \AA$ showed up in the wide-angle region (indicated a WA), which corresponds to the average lateral distance between fully extended acyl chains organized with rotational disorder in hexagonal packing. The figure discloses that after exposure to $P$. magellanica in the range $10 \mu \mathrm{M}-10 \mathrm{mM}$ GAE there was a gradual weakening of the low- and wide-angle lipid reflection intensities. From these results it can be concluded that the extract produced a structural perturbation of the polar and acyl regions of DMPC bilayers. Results from similar experiments with DMPE are presented in Fig. 3B. The fact that only one strong reflection of $56.4 \AA$ is observed in the low-angle region and the presence of the $4.2 \AA$ in the wideangle region are indicative of the gel state reached by DMPE in water after heating and cooling it. Increasing concentrations of the plant extract in the range $10 \mu \mathrm{M}-10 \mathrm{mM}$ GAE only induced a slight gradual increase of the lowangle reflection intensities. Thus, the extract induced a very moderate molecular order of DMPE bilayers. Figures $3 \mathrm{C}$ and 3D show the protective effect of $P$ magellanica against the oxidative action of $\mathrm{HClO}$. As it can be appreciated in Fig. 3C, $0.05 \mathrm{mM} \mathrm{HClO}$ induced a significant reduction of DMPC low- and wide-angle reflection intensities indicating a structural perturbation of DMPC bilayers. However, a concentration as low as $0.1 \mu \mathrm{M}$ (GAE) P. magellanica neutralized the deleterious effect of $\mathrm{HClO}$. Fig. 3D shows the same protective effect of $0.1 \mu \mathrm{M}$ (GAE) P. magellanica extract against $0.50 \mathrm{mM} \mathrm{HClO}$.
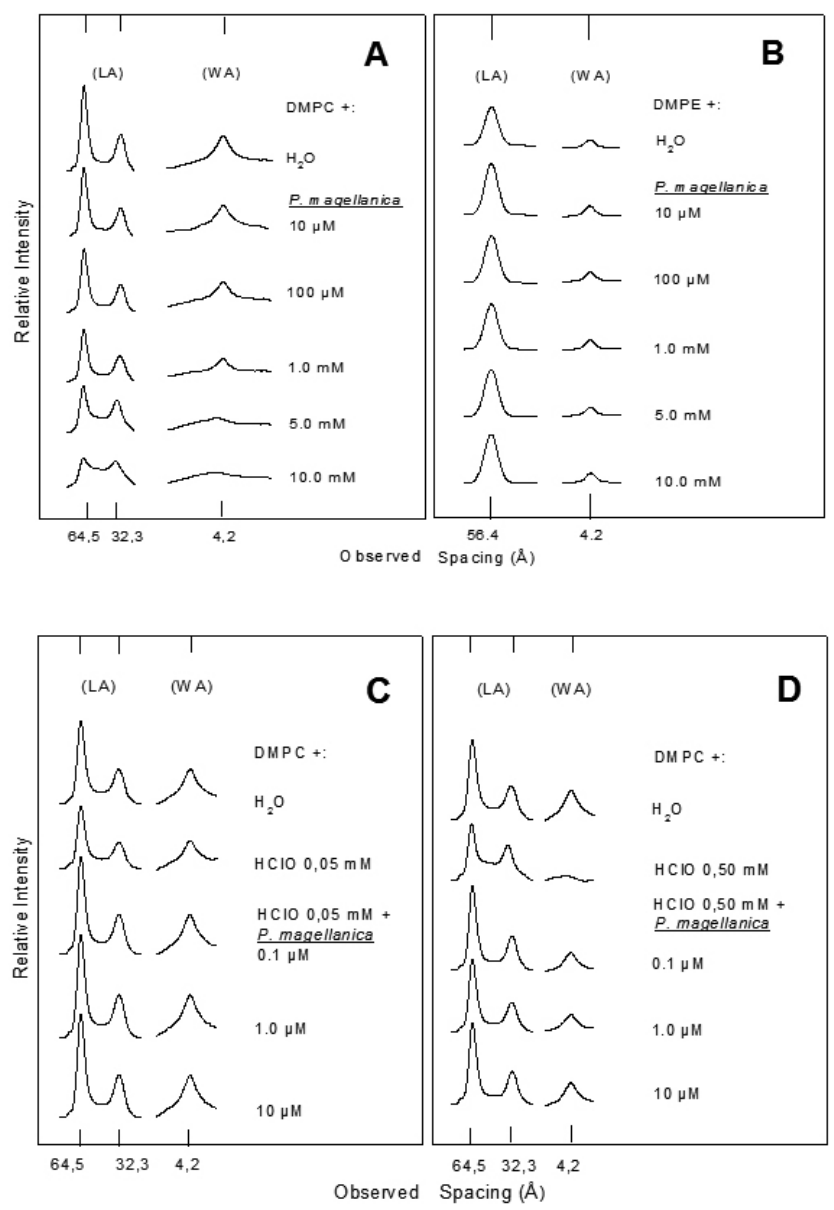

Fig. 3 Microdensitograms from X-ray diffraction patterns of (A) dimyristoylphosphatidylcholine (DMPC) and (B) dimyristoylphosphatidylethanolamine (DMPE) in water and aqueous extracts of P. magellanica; (C) DMPC $+0.05 \mathrm{mM} \mathrm{HClO}+$ aqueous extracts of $P$. magellanica; (D) DMPC $+0.5 \mathrm{mM} \mathrm{HClO}+$ aqueous extracts of $P$. magellanica. (LA) low-angle and (WA) wide-angle reflections. Extract concentrations are expressed as gallic acid equivalents (GAE).

3.3. Scanning electron microscopy (SEM) studies of human erythrocytes

Human erythrocytes incubated with $50 \mu \mathrm{M} \mathrm{HClO}$ induced spherocytosis (sphere-shaped rather than bi-concave disk shaped) and anisocytosis (red blood cells of abnormal size) in a considerable number of erythrocytes (Fig. 4B). However, this shape alteration of the normal red blood cells (Fig. 4A) was highly attenuated in samples containing $50 \mu \mathrm{M} \mathrm{HClO}$ and $1 \mu \mathrm{M}$ GAE of $P$. magellanica (Fig. 4C). These results demonstrated the highly protective effect of $P$. magellanica against the shape and size perturbing effect of $\mathrm{HClO}$ upon human erythrocytes. 
(A)

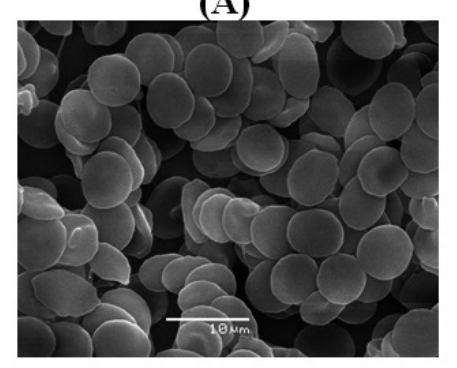

(B)

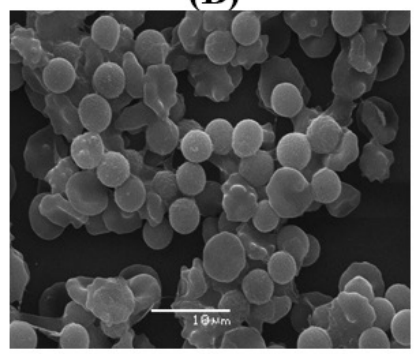

(C)

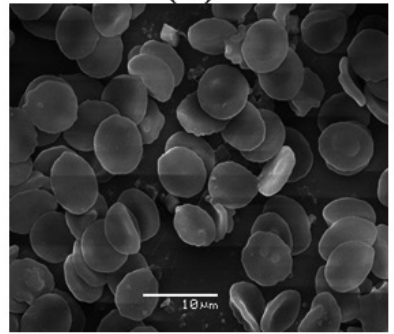

Fig. 4 Effects of P. magellanica aqueous extracts and $\mathrm{HClO}$ on morphology of human erythrocytes. (A) Untreated erythrocytes; (B) erythrocytes incubated with $50 \mu \mathrm{M} \mathrm{HClO}$; (C) erythrocytes incubated with $1 \mu \mathrm{M}$ (GAE) P. magellanica aqueous extract and $50 \mu \mathrm{M} \mathrm{HClO}$. Extract concentrations are expressed as gallic acid equivalents (GAE).

\subsection{Hemolysis assays}

Fig. 5 shows that $0.25 \mathrm{mM} \mathrm{HClO}$ induced a $70 \%$ hemolysis in human erythrocytes. On the other hand $0.02 \mathrm{mM}$ (GAE) and increasing concentrations of the plant extract considerably reduced the hemolytic effect of $\mathrm{HClO}$.

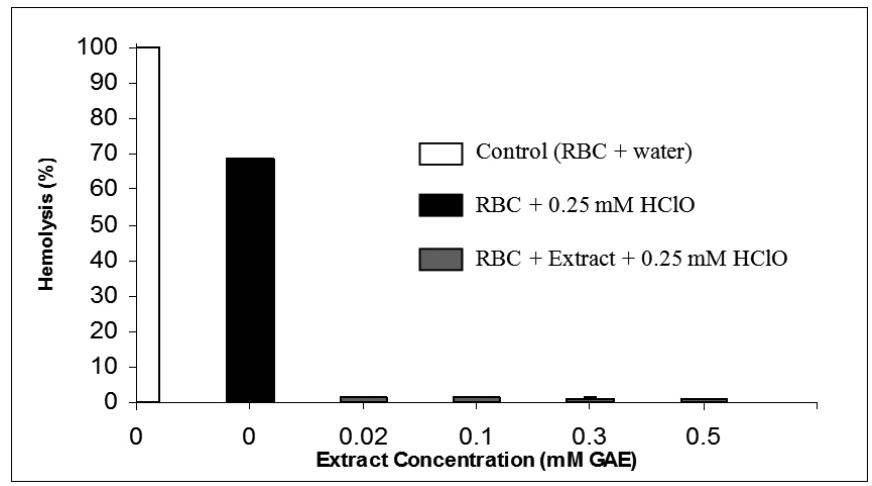

Fig. 5 Percentage of hemolysis of red blood cells (RBC) incubated with $0.25 \mathrm{mM} \mathrm{HClO}$ and different concentrations of $P$. magellanica aqueous extracts. Extract concentrations are expressed as gallic acid equivalents (GAE); $\mathrm{n}=3$. Values are the mean $\pm \mathrm{SD}$.

\section{DISCUSSION}

The protective effects of aqueous extracts of $P$. Magellanica were evaluated on human erythrocytes and molecular models of the erythrocyte membrane exposed to $\mathrm{HClO}$-induced oxidative stress. $\mathrm{HClO}$ is an extremely toxic biological oxidant generated by neutrophils and monocytes. ${ }^{21}$ However, because it readily reacts with a range of biological targets it has been difficult to identify which reactions are critical for its cytotoxic effects. ${ }^{37}$ Human erythrocytes are a reliable and easily obtainable mechanism to detect oxidative stress. ${ }^{11}$ Although the exact mechanism is not clear the cell membrane is considered the primary site for reaction. $\mathrm{HClO}$ treatment of erythrocyte membrane results in changes of membrane fluidity, surface area, and morphological transformations, events that precede cell lysis. ${ }^{21,31,37}$ Our SEM observations showed that $50 \mu \mathrm{M} \mathrm{HClO}$ induced morphological alterations to the red cells, from a discoid to a spherocytic form. According to the bilayer couple hypothesis shape changes induced in erythrocytes by foreign molecules are due to differential expansion of the two monolayers of the red cell membrane. ${ }^{38-39}$ Thus, stomatocytes are formed when the compound is inserted into the inner monolayer whereas spiculated-shaped echinocytes are produced when is situated into the outer moiety. Battistelli et al. reported that $0.5 \mathrm{mM} \mathrm{HClO}$ induced the formation of echinocytes in most of the observed erythrocytes. ${ }^{11}$ This effect might be due to the interaction of $\mathrm{HClO}$ with phosphatidylcholines located in the outer monolayer of the red cell membrane as we observed in our X-ray experiments (Fig. 2 D). This result does not agree with that reported by Vissers and Winterbourn who indicated that $\mathrm{HClO}$ penetrates into the red cells passing through the hydrophobic lipid bilayer without the membrane acting as a major barrier. ${ }^{24}$ Our finding that the formation of spherocytes with $50 \mu \mathrm{M} \mathrm{HClO}$ might be due to the interaction of $\mathrm{HClO}$ with membrane cytoskeleton. ${ }^{37,40}$ The result that a concentration as low as $1 \mu \mathrm{M}$ GAE $P$. magellanica practically neutralized the effect of a 50 -fold higher $\mathrm{HClO}$ concentration $(50 \mu \mathrm{M})$ demonstrated the protective capacity of the plant extract against the erythrocyte shape change capacity of $\mathrm{HClO}$. On the other hand, very low concentrations of the extract considerably reduced the deleterious capacity of $\mathrm{HClO}$ to induce red blood cell hemolysis.

We also examined by X-ray diffraction the interaction of $P$. magellanica with DMPC and DMPE. Results showed that $10 \mu \mathrm{M}$ (GAE) and higher extract concentrations disordered the polar and acyl chain regions of DMPC bilayers whereas DMPE bilayers were not significantly affected by $P$. magellanica even at the highest assayed concentration (10 mM GAE). DMPC and DMPE differ only in their terminal amino groups, these being ${ }^{+} \mathrm{N}\left(\mathrm{CH}_{3}\right)_{3}$ in $\mathrm{DMPC}$ and ${ }^{+} \mathrm{NH}_{3}$ in DMPE. DMPE molecules pack tighter than those of DMPC due to their smaller polar groups and higher effective charge, resulting in a very stable bilayer system. However, the hydration of DMPC results in water filling the highly polar interbilayer spaces with the resulting increase of their width. This phenomenon allows the incorporation of polyphenols into DMPC bilayers and their consequent interaction by hydrogen-bonding with the lipid polar head groups. Our experimental results showed that $0.1 \mu \mathrm{M}$ GAE $P$. magellanica neutralized the deleterious effects of 0.05 and $0.5 \mathrm{mM} \mathrm{HClO}$. Thus, molecules present in $P$. magellanica aqueous extract would act by blocking access of oxidants into the lipid bilayer contributing to preserve the structure and functions of biological membranes. In conclusion, the experiments carried out on human erythrocytes and molecular models of the red cell membranes demonstrated the antioxidant properties of $P$. magellanica aqueous extracts.

\section{ACKNOWLEDGEMENTS}

To FONDECYT (1130043) and DIUC-PATAGONIA (205.024.032-1).

\section{REFERENCES}

1. C. McEwan, L.A. Borrero, A. Prieto eds. Patagonia: Natural History, Prehistory and Ethnography at the Uttermost End of the Earth, Princeton University Press/British Museum Press, 1997.

2. J.B. Harborne, C.A. Williams, Phytochemistry 55, 481, (2000)

3. L. Hou, B. Zhou, L. Yang, Z. Liu, Org. Biomol. Chem. 2, 1419, (2004)

4. B. Chance, H. Sies, A. Boveris, Physiol. Rev. 59, 527, (1979)

5. M.R. McCall, B. Frei, Free Radical Bio. Med. 26, 1034, (1999)

6. R.S. Sohal, R. Weindruch, Science 273, 59, (1996)

7. A. Arora, M.G. Nair, M. Strasburg, Free Radical Bio. Med. 24, 1355, (1998)

8. S. Chaudhuri, A. Banerjee, K. Basu, B. Sengupta, P.K. Sengupta, Int. J. Biol. Macromol. 41, 42, (2007)

9. G. Galati, P.J. O’Brian, Free Radical Bio. Med. 37, 287, (2004)

10. M. Barbosa-Ferreira, M.L.Z. Dagli, P.C. Maiorka, S.L. Górniak, Food Chem.Toxicol. 43, 297, (2005)

11. M. Battistelli, R. De Sanctis, R. De Bellis, L. Cucchiarini, M. Dachà, P. Gobbi, Eur. J. Histochem. 49, 243, (2005)

12. T. Srour, Y.Y. Bilto, M. Juma, M.R. Irhimeh, Clin. Hemorheol. Micro. 23, $13,(2000)$

13. J.M. Boon, B.D. Smith, Med. Res. Rev. 22, 251, (2002)

14. P.F. Devaux, A. Zachawsky, Chem. Phys. Lipids 73, 107, (1994)

15. M. Suwalsky, P. Orellana, M. Avello, F. Villena, C.P. Sotomayor, Food Chem. Toxicol. 44, 1393, (2006)

16. M. Suwalsky, P. Orellana, M. Avello, F. Villena, Food Chem. Toxicol. 45, $130,(2007)$ 
17. M. Suwalsky, M. Avello, J. Membr. Biol. 247, 703, (2014)

18. M. Suwalsky, P. Vargas, M. Avello, F. Villena, C.P Sotomayor, Int. J. Pharm. 363, 85, (2008)

19. M. Suwalsky, K. Oyarce, M. Avello, F. Villena, C.P Sotomayor, Chem.Biol. Interact. 179, 413, (2009)

20. T. Tatsumi, H. Fliss, Am. J. Physiol. 267, 1597, (1994)

21. I.B. Zavodnik, E.A. Lapshina, L.B. Zavodnik, G. Bartosz, M. Soszynski, M. Bryszewska, Free Radical Bio.Med. 30, 363, (2001)

22. C.L. Hawkins, M.J. Davies, J. Biochem. 332, 617, (1998)

23. A.C. Carr, M.C.M. Vissers, N.M. Domigan, C.C. Witerbourn, Redox Rep. 3, 263, (1997)

24. M.C.M. Vissers, C.C. Winterbourn, Biochem. J. 307, 57, (1995)

25. J.C. Morris, J. Phys. Chem. 70, 3798, (1966)

26. Y.S. Vegliolu, G. Mazza, L. Gao, B.D. Oomah, J Agr. Food Chem. 46, 4113, (1998)A. 27. O.K. Chun, D.-O. Kim, Food Res. Int. 37, 337, (2004)

28. J.B. Harborne, Phytochemical Methods: A Guide to Modern Techniques of Plant Analysis. London, Chapman \& Hall, (1998).

29. A. Stojakowska, J. Malarz, A. Szewczyk, W. Kisiel, Acta Physiol. Plant. 34, 291, (2012)
30. B. Zimmermann, D.M. Soumpasis, Cell. Biophys. 7, 115, (1985)

31. P. Malheiros, M.A. Brito, D. Brites, M.N. Correa, Chem-Biol. Interact. 126, 79, (2000)

32. M.A.Vives, M.R. Infante, E. Garcia, C. Selve, M. Maugras, M.P. Vinardell Chem.-Biol. Interact. 118, 1, (1999)

33. E. Beutler, Red Cell Metabolism. A Manual of Biochemical Methods, Grune \& Straton, New York, 1975

34. J. Malarz, A. Stojakowska, W. Kisiel, Appl. Biochem. Biotechnol. 171, 1589, (2013)

35. G.A. Mohamed, S.R.M. Ibrahim, ARKIVOC 15, 281, (2007)

36. M. Suwalsky, Phospholipid bilayers in J.C. Salamone, ed. Polymeric Materials Encyclopedia, CRC, Boca Raton, 1996, pp. 5073-5078.

37. M.C.M. Vissers, A.C. Carr, A.L.P. Chapman, Biochem. J. 330, 131, (1998)

38. M.P Sheetz, S.J. Singer, P. Natl Acad. Sci. USA 71, 4457 (1974)

39. G. Lim, M. Wortis, R. Mukhopadhyay, P. Natl. Acad. Sci. USA 99, 16766, (2002)

40. S. Eber, S.E. Lux, Semin. Hematol. 41, 118, (2004) 